\title{
A Note on the American Law Institute
}

The American Law Institute was founded in 1923 and is based in Philadelphia. The Institute, through a careful and deliberative process, drafts and then publishes various restatements of the law, model codes, and other proposals for legal reform "to promote the clarification and simplification of the law and its better adaptation to social needs, to secure the better administration of justice, and to encourage and carry on scholarly and scientific legal work." Its membership consists of judges, practicing lawyers, and legal scholars from all areas of the United States as well as some foreign countries, selected on the basis of professional achievement and demonstrated interest in the improvement of the law. The Institute's incorporators included Chief Justice and former President William Howard Taft, future Chief Justice Charles Evans Hughes, and former Secretary of State Elihu Root. Judges Benjamin N. Cardozo and Learned Hand were among its early leaders.

The Institutes's restatements, model codes, and legal studies are used as references by the entire legal profession.

The American Law Institute's website is http://www.ali.org 